\title{
'Islamic' Bawean Cultural Identity in Tradition
}

\author{
${ }^{1}$ Sri Wiryanti Budi Utami, ${ }^{2}$ Bea Anggraini \\ $\left\{\underline{1}\right.$ sri-w-b-o@fib.unair.ac.id, ${ }^{2}$ bea.anggraini@yahoo.co.id $\}$ \\ 1,2 Airlangga University
}

\begin{abstract}
Bawean is an island inhabited by several settled tribes. One of its unique phenomena of worthy observed is on their recognition as a unit that calls themselves Bawean people and Muslims. Bawean people who bear their population as only Islam assumes the developed Islamic culture in Bawean thickly nuances the people's traditions. This study seeks to explore on how Bawean people's attitudes in interpreting their tradition as a hallmark of Islamic cultural identity. The ethnographic method was followed by the 'thick description' technique were used in this study to formulate the Bawean people in interpreting the Islamic cultural identity in such tradition. The findings showed that Islam and culture are integrated in people's lifeviews, socio-cultural practices, and practical doings of Islamic teachings. Reciting the Qur'an has been part of the people's main ritual. The Bawean people interpret their traditions as their typical expressions of Islamic culture. The entire ritual of carrying out the traditions in Bawean is based on Islamic religious practices which show that Islam has one God, the one perfected holy book called alQur'an, and one last Prophet, the Prophet Muhammad. Islamic culture in tradition becomes a place of friendship and kinships, a means of building identity, a sense of unity in Bawean locality..
\end{abstract}

Keywords: Islamic culture, tradition, life viewpoints, Bawean

\section{Introduction}

Islam is the only belief embraced by the Bawean people. There is no other religion, apart from Islam developing in Bawean. Islam is the cohesive basis of the tribes who settled in Bawean. Bawean is likened, Sumatra + Java + Sulawesi + Borneo $=$ Bawean [1]. The tribes in Bawean define unity in locality with the name Bawean people. They view the values of Islam can be the basis of integrative and belief in overcoming the life problems living in Society. Religious beliefs shape the way humans deal with problems. The values reflected in it and its implementation practices turn people to believe and feel safe in confronting disasters; [2]. Religion as a cultural orientation has been a means of social cohesion, it additionally reflects power to transcend boundaries established by ethnic origin [3]. Islamic Culture is the reality of Islam in socio-cultural practices that tend to be exclusive in their locality.

Tradition as a local culture culturally realizes the values, attitudes and procedures which are all believed by the community in meeting their needs. Tradition serves to increase community solidarity and togetherness that foster a sense of unity [4]. Bawean people believe in Islamic culture as a synonymous feature with their society. A belief illustrates that Islamic 
culture in the tradition is run into an inherent ownership. They believe as the basis when individuals confronted with the situation to state who they are. As is known, Bawean people are often equated with Madurese due to the language similarity.

Bawean people have long been known as people who carry out the tradition of wandering. Practically, the activities of migrating Bawean people are different from migrating to other communities. For Bawean people, wandering is not only a matter of economic interests, but a tradition. The tradition of wandering is a cultural heritage. Tradition as a cultural system provides a model that regulates behavior [5]. This study explores the reasons behind the Bawean people realizing Islamic teachings in tradition as a form of Islamic culture.

\section{Research Method}

This study was designed with descriptive qualitative approach, in addition to ethnographic method of communication. The ethnographic method is one of the qualitative traditions to test and analyze the cultural values of a community. [6] The 'thick description' is a technique which enables the researchers to describe culture as it is. This research model was chosen for it provides detailed descriptions of individuals about their experiences and meanings as the existing life in the society. The interview was conducted with a number of guiding questions about the Bawean people's perspective towards their traditions, language, culture and understanding of the tribal diversity who settled in Bawean.

\section{Results And Discussion}

The 'Islamic' culture in Bawean is reflected in the importance of Islamic boarding school or pondok as a place for teaching and learning activities. The traditionally educating children in Bawean are spent studying in the Islamic boarding school. After having reached the adulthood 'aqil baligh' male students normally spend time studying in the Islamic boarding school. In addition, the 'pondok' becomes a place which resolves customary violations; the Fatwa is the source of determining sanctions for all violations. All the customs and practices in the celebration and the great events glorify the holy verse 'Al Qur'an'. Islam is the only belief; there are no other religious buildings other than the mosques. Being a Bawean person it requires someone to embrace the Islamic belief. Islamic teaching is a life guidance for the Bawean people. This is reflected in Bawean philosophy "Bhentalnya benthal sadhet, Sapoknya sapok iman, Pajhungnya pajhung Allah" This philosophy shows that the Bawean people can never be separated from the shahadah or Islamic testimonial faith, in addition to rely on the divine contemplation to Allah. The phrase "bhentalnya benthal sadhet" (the pillow is the Islamic testimonial faith) symbolically means the Baweanese beginning from the birth to death they bear shahadah or testimonial faith. By reading shahadah, it is a prerequisite for a Muslim's life and dies as the people of Bawean. Whereas the "sapoknya sapok iman" (the people's blanket is their faith), which implies that all Bawean people believe in Islam as part of following the Prophet Muhammad's practices.

\subsection{The'Molod' Tradition}

The 'Molod' tradition in Bawean is celebrated with a series of activities, cleaning and decorating mosques, village meetings, 'asyrakalan' (religious preaching and ceremonial events) 'angkatan' (food to be distributed). Bawean people consider the 'molod' tradition a 
tradition that must be celebrated royally and joyfully. The 'molod' celebration exceeds its peak than welcoming Eid al-Fitr, Eid al-Adha. For Bawean people celebrating 'Molod' is the same as welcoming a new life. They consider celebrating the birth of the prophet Muhammad as a symbol of acceptance of Islam as a living gift. The decoration that adorns the Mosque, Surau and 'angkatan' has philosophical value to the greatness of the Prophet Muhammad. Using trinkets that decorate decorations in mosques, such as a banana tree with a bunch of fruit, a bunch of coconuts, cassava trees with sweet potatoes, symbolizing the birth of Muhammad, one noble person who brought fertility to the earth. Stump decoration as a miniature of shady trees and fruit stuck in the middle of the 'angkatan', which implies the symbolic value of the prophet Muhammad's birth, he was believed to be a bearer of protection for the people. The decoration of salted eggs made of duck eggs embedded in bamboo blades as much as 12 pieces around the angkatan, which symbolizes the birth of the prophet on 12 Rabiullawal and his teachings need to be firmly guarded. Marinated duck eggs symbolize that the teachings of Muhammad bring order to mankind. The excitement of the Molod tradition at Bawean normally will be marked a week before the Molod ceremony, residents prepare it with joy. They worked together and carried out "ater-ater" a typical activity which means sharing. After the celebration is accomplished, the decoration at the mosque are the contested material at the 'auction'. Bawean people give each other high appreciation as a form of happiness in celebrating 'the molod'.

\subsection{The Tradition of Wandering}

The tradition of wandering (Indo.'merantau') 'traveling to get a job or seek experience' is a mandatory tradition, especially for all Bawean men. The tradition of migration has been going on for centuries, reflected, in 1849 there were already Bawean people in Singapore at that time known as the Malacca region. [7], [8]. Around 1850 approximately three hundred Baweans settled on the banks of a small branch of the Saigon River in Vietnam [9]

Wandering to abroad for Bawean people is not merely an activity intended solely to meet the necessities of life, but also as a cultural tradition. Being a Bawean person should be willing and brave to migrate. Therefore, it is not surprising that Bawean men at least in their lives must have migrated. For men who want to settle down, wandering becomes the main prerequisite for proposing a girl. this is illustrated in the following piece of advice.

Ajj moka?-moka? samper? mon ghita angarsai lange?,

Ben ajjo ngoker lange? mon ghita ngoasae elmo lahir ben elmo batin.

Do not open sewek or traditional cloth worn by women, if you have not carved the sky, do not carve the sky if you have not mastered both physical and mental knowledge.

(Never hold a marriage before wandering, never wish to go wandering before having mastered proficient martial arts and the holy book of Qur'an)

The tradition of wandering is as if a condition and a test of life and forms an attitude of responsibility, in addition to being a characteristic that indicates the level of Islam of a Bawean. Before going to wandering, one must have a understanding about the Qur'an as a guide to living a noble behavior.

\subsection{The Traditional Marriage of Bawean}

The 'Islamic' culture deeply inspires all socio-religious activities in the Bawean marriage tradition at a ceremony called 'ngalose', it is a must for the bride to read the Qur'an in a typical way 'qiroat'. The ceremony of 'ngalose' is a well-maintained tradition of learning to read the al-Qur'an recited by the bride, before the reception celebration is going to be held. 


\subsection{Pencak Bawean/ Typical Martial Art from Bawean}

Pencak art has become a hallmark of Bawean culture. The symbol of Bawean pencak is a sword named Dzulfakar, is the sword's name of an Islamic figure, the Companion of the Prophet Muhammad, named Ali bin Abu Tholib. Pencak Bawean is a movement art which has philosophical value to realize the teachings of Islam [10]

Islamic culture becomes synonymous with the form and style of its people, through understanding Islam as a way of life and socio-cultural practices. This reality that underlies the Bawean people would rather express Bawean as the absolute community who only embrace Islam, rather than being marked as part of Madura culture. This shows the problem of identity, the way individuals from their collectiveness distinguish themselves from other individuals with different assumptions, emotions, loyalties, affiliations, and social commitments [11], [12]. Cultural identity as a way for certain individuals or groups to orient themselves according to their existence in their socio-cultural environment. That shows the traditional ritual in defining an identity. The rituals carried out and have become traditions are a series of actions that are consciously carried out based on customs or religion. Cultural identity as 'identity' is a personal or collective understanding of the values, norms, goals, and practices of someone's actions in their social life referring to religious values. Cultural identity is built from togetherness as entities that occupy an area, interacting according to a system of customs, where they are morally and religiously bound as a community [13]

Based on the facts of the Bawean people described earlier, that their traditions and culture are a unifying factor in shaping the identity of the Bawean people. Tradition is a form of culture. As a form of customs, tradition is passed down for generations to be carried out by society and where in general a tradition that is carried out is considered the most good and right by the bearers. Tradition is a medium to interpret the local culture, which gives a distinctive color to the locality of the community.

\section{Conclusion}

Islam for Bawean people is as a unifier for the diversity of tribes in Bawean. For them, people's identities do not necessarily assume that identity is fully related to authenticity. The value of Islamic beliefs as a norm of behavior is binding on all people who claim to be Bawean people. Bawean identity is realized in traditions and cul.tures that embrace Islamic teachings Bawean people do not emphasize tribal origin, but prioritize Islam as the basis of their identity. Each ethnic group in Bawean no longer refers to themselves as a tribe from their original territory. These people voluntarily melt themselves into 'Bawean people', where Islam is the social glue. In Bawean, Islam is the only belief, therefore Bawean residents claim that Islam is the only condition for becoming a Baweanese.

The entire ritual of carrying out traditions at Bawean is based on Islamic religious practices, teachings that show Islam has one God, one holy book of the Koran, and one Prophet Muhammad. Bawean people define Islamic cultural identity in various traditions as a Muslim community that obeys Allah, loves Rasullulah SAW. Living the tradition is a form of love for the Prophet Muhammad, sincerity, sacrifice, responsibility, mutual cooperation, and togetherness to strengthen social order. Islamic culture in tradition becomes a means of building identity, a sense of unity in Bawean cultural locality. 


\section{Acknowledgment}

This paper is the result of language and cultural research at Bawean. Thanks to Ristekdikti and Airlangga University for funding research at Bawean

\section{References}

[1] D. Kartono, Orang Bawean dan Boyan: Perubahan dan Pembentukan Identitas Masyarakat Bawean. Gresik: Boyan Publishing, 2004.

[2] Vancano, "The Religious Dimension of Coping: The Roles of Cosmologis and Religious Practices," Int. Ref. Res., pp. 245-264, 2014.

[3] Fukuyama, "Social Capital and Development: The Coming Agenda," in Social Capital and Poverty Reduction In Latin America and The Caribbean: Toward A New Paradigm, 2001, pp. 24-26.

[4] Fuad, "Makna Simbolik Tradisi Nyadran," J. Din. Penelit., vol. 2, pp. 123-134, 2013.

[5] Maimunah, "Tradisi Baayun Mulud di Banjarmasin," J. Al-Banjari, vol. 11, no. 1, 2012.

[6] J. W. Creswell, Qualitative Inquiry and Research Design, Choosing Among FiveTraditions. California: Sage Publication, 2015.

[7] J. Vredenbregt, Bawean dan Islam: Terjemahan dari Baweanners in Hub Moederland en in Singapore, Seri INIS. Jakarta: Indonesian Netherlands Cooperation in Islamic Studies (INIS), 1990.

[8] Usman, Petodhu Bhesa Bhebien. Bawean: Next Generation Foundation, 1996.

[9] M. Stokhof, "State Classification and It's Discontents The Struggle Over Bawean Ethnic Identity in Vietnam," J. Vietnamese Stud., vol. 4, no. 2, pp. 154-195, 2009.

[10] Asyhar, Pesantren Hasan Jufri, Dari Masa ke Masa, Sejarah dan Realitas. Depok: Keira Publishing, 2017.

[11] R. Jenkins, Social Identity. London: Routledge, 2004.

[12] A. Schnabel, "How the Religious Cleavages of Civil Society Shape National Identity," Sage OPen, pp. 1-14, 2014.

[13] Koentjaraningrat, Pengantar Ilmu Anthropologi. Jakarta: Aksara Baru, 2002. 